\title{
PENAMBAHAN TEPUNG Spirulina PADA PAKAN TERHADAP TINGKAT KELANGSUNGAN HIDUP DAN PERKEMBANGAN LARVA UDANG GALAH (Macrobrachium rosenbergii de Man)
}

\author{
Effect of Addition of Spirulina Flour to Feed on Survival Rate and Development \\ of Giant prawn larvae (Macrobrachium rosenbergii de Man)
}

\author{
Rahmat Zulmi $^{1}$, Sumantriyadi ${ }^{2}$ dan Supriyadi ${ }^{2}$
}

1) Alumni Fakultas Perikanan Universitas PGRI Palembang

2) Staf Pengajar Fakultas Perikanan Universitas PGRI Palembang Email : perikanan.pgri@gmail.com

\begin{abstract}
Abstrak
Penelitian ini bertujuan untuk menentukan dosis terbaik penambahan tepung spirulina pada pakan egg custard, untuk mengukur tingkat kelangsungan hidup larva Udang Galah dan untuk mengukur perkembangan larva Udang Galah. Penelitian ini dilakukan di Balai Besar Perikanan Budidaya Air Tawar (BBPBAT) di Instalasi Pembenihan Udang Galah (IPUG), Pelabuhan Ratu, Jawa Barat. Metode penelitian ini menggunakan metode Rancangan Acak Lengkap (RAL) yang terdiri dari 4 taraf perlakuan dan 3 ulangan. Pada P0 (kontrol), P1 (penambahan tepung spirulina 5 gram), P2 (penambahan tepung spirulina 10 gram) dan P3 (penambahan tepung spirulina 15 gram). Hasil penelitian menunjukkan bahwa penambahan tepung spirulina pada pakan berpengaruh tidak nyata terhadap tingkat kelangsungan hidup dan perkembangan larva udang galah. Tingkat Kelangsungan Hidup rata-rata larva udang galah pada perlakuan yaitu P3 25,67\%, P0 25,17\%, P1 21,83\% dan P2 20,67\%. Perkembangan rata-rata larva Udang Galah dimulai dari stadia 4,86 sampai stadia 11,85. Kualitas air berkisar P0: pH 7,14-8,35, DO 5,6-6,0 $\mathrm{mg} / \mathrm{l}$, salinitas $14-15 \mathrm{ppt}$, suhu $28-30{ }^{\circ} \mathrm{C}$ dan amonia 0,34-1,17 mg/l. P1: pH 7,15-8,0, DO 5,7-5,8 mg/l, salinitas 14-15 ppt, suhu $28-30^{\circ} \mathrm{C}$ dan amonia 0,79-1,17 mg/l. P2: pH 7,12-8,30, DO 5,3-5,6 mg/l, salinitas $14-15 \mathrm{ppt}$, suhu $28-30^{\circ} \mathrm{C}$ dan amonia 1,17-1,40 mg/l. P3: pH 7,12-8,0, DO 5,3-5,8 mg/l, salinitas 14-15 ppt, suhu $28-30^{\circ} \mathrm{C}$ dan amonia $1,05-1,17 \mathrm{mg} / \mathrm{l}$.
\end{abstract}

Kata Kunci : Larva Udang Galah, Spirulina, tingkat kelangsungan hidup, perkembangan

\begin{abstract}
This study aims to determine the best dose of spirulina flour in custard egg feed, to measure the survival rate of Giant prawn larvae and to measure the development of giant prawn larvae. This research was conducted at Balai Besar Perikanan Budidaya Air Tawar (BBPBAT) at Instalasi Pembenihan Udang Galah (IPUG), Pelabuhan Ratu, West Java. This research method used Random Design Complete (RAL) which consists of 4 treatment levels and 3 replications. In PO (control), P1 (announcement of 5 gram spirulina flour), P2 (announcement of 10 gram spirulina flour) and P3 (announcement of 15 gram spirulina flour). The results showed that the addition of spirulina flour to the feed was not significant to the survival rate and the development of giant prawn larvae. The average survival rate of prawn larvae during treatment was P3 25.67\%, P0 25.17\%, P1 21.83\% and P2 20.67\%. The average record of giant prawn larvae starts from stadia 4.86 to 11.85 stadia. Water quality P0: $\mathrm{pH}$ 7,14-8,35, DO 5,6-6,0 mg/l, salinity 14-15 ppt, temperature $28-30^{\circ} \mathrm{C}$ and ammonia 0,34-1,17 mg/l. Pl: $\mathrm{pH} \mathrm{7,15-8,0,} \mathrm{DO} \mathrm{5,7-5,8} \mathrm{mg} /$, salinity 14-15 ppt, temperature $28-30^{\circ} \mathrm{C}$ and ammonia 0,79-1,17 mg/l. P2: pH 7,12-8,30, DO 5,3-5,6 $\mathrm{mg} / \mathrm{l}$, salinity $14-15 \mathrm{ppt}$, temperature $28-30^{\circ} \mathrm{C}$ and ammonia 1,17-1,40 mg/l. P3: pH 7,12-8,0, DO 5,3-5,8 $\mathrm{mg} / \mathrm{l}$, salinity $14-15 \mathrm{ppt}$, temperature $28-30^{\circ} \mathrm{C}$ and ammonia 1,05-1,17 $\mathrm{mg} /$.
\end{abstract}

Keywords: Giant prawn larvae, Spirulina, survival rate, development 


\section{PENDAHULUAN}

Udang Galah merupakan Udang yang paling populer dari keseluruhan Udang air tawar dikarenakan ukuran tubuhnya yang besar dan memiliki nilai ekonomi yang tinggi baik di pasar domestik maupun luar negeri (Priyono dkk., 2011). Udang Galah menempati dua habitat yaitu perairan payau dan tawar. Pada saat dewasa dan siap melakukan pemijahan sampai telur menetas menjadi larva stadia 11 (usia 2 hari hingga 40 hari) berada di muara sungai dengan kondisi payau. Setelah juvenil sampai usia dewasa, Udang Galah hidup di perairan tawar (Murtidjo, 2010 dalam Taqwa, 2012).

Biasanya larva Udang Galah diberikan pakan alami berupa artemia, namun artemia harganya cukup mahal. Untuk menekan biaya pakan, maka larva diberikan pakan buatan tambahan berupa egg custard. Rohmana (2017), menyatakan bahwa pemberian pakan larva Udang Galah berupa artemia dan egg custard diberikan secara bergantian. Menurut Satria dan Novrizah (2013), pada saat larva Udang Galah sangat rentan akan kematian sehingga perkembangan awal sangat menentukan dalam budidaya Udang Galah. Untuk meningkatkan kelangsungan hidup larva Udang Galah perlu adanya penambahan bahan baku pada pakan yang dapat meningkatkan sistem kekebalan tubuh salah satunya dengan penambahan Spirulina.

Menurut Utomo dan Prabakusuma (2009), Spirulina platensis diketahui memiliki pengaruh yang baik pada sistem kekebalan. Spirulina. platensis merupakan salah satu alga hijau biru (cyanophyceae) yang banyak tersebar di perairan tropis dan dapat tumbuh dengan baik di perairan tawar maupun perairan laut. Spirulina platensis merupakan sumber hayati yang dapat memproduksi berbagai senyawa kimia yang dapat dimanfaatkan sebagai suplemen maupun sumber obat alami yang berpotensi sebagai antioksidan (Firdiyani dkk., 2015). Selain itu Spirulina platensis juga mampu merangsang pembentukan sel darah merah dan darah putih yang berperan penting dalam sistem kekebalan tubuh (Kozlenko dan Henson, 1998 dalam Setyawan dan Satria, 2013). Senyawa kimia tersebut berupa pigmen biru gelap karena mengandung phycocyanin (Kozlenko dan Henson, 1998 dalam Setyawan dan Satria, 2013).

Hasil penelitian Arlyza dan Silveira (2005), dalam Utomo dan Prabukusuma (2009), diketahui bahwa phycocyanin mempunyai fungsi penting sebagai antioksidan.
Antioksidan didefinisikan sebagai senyawa yang melindungi sel dari efek berbahaya radikal bebas reaktif (Utomo dan Prabukusuma 2009). Phycocyanin mempunyai kandungan yang cukup signifikan sebagai antioksidan, melindungi fungsi hati, dan membuang senyawa radikal (Weil, 2000 dalam Setyawan dan Satria, 2013). Tujuan dalam penelitian ini adalah sebagai berikut: 1). Untuk menentukan dosis terbaik penambahan tepung spirulina pada pakan egg custard, 2). Untuk mengukur tingkat kelangsungan hidup larva Udang Galah dan 3). Untuk mengukur perkembangan larva Udang Galah

\section{METODE PENELITIAN}

Penelitian ini dilaksanakan selama 21 hari yang dimulai pada tanggal 13 Desember 2017 sampai tanggal 2 Januari 2018 di Instalasi Pembenihan Udang Galah Balai Besar Perikanan Budidaya Air Tawar (IPUG BBPBAT) Sukabumi, Jalan Raya Cisolok KM. 12 Desa Karang Papak Pelabuhanratu Provinsi Jawa Barat. Penelitian ini bersifat metode eksperimen (uji coba) dimana untuk menguji efektif atau tidaknya suatu penelitian. Penelitian ini menggunakan Rancangan Acak Lengkap (RAL) dengan 4 taraf perlakuan dan 3 ulangan :

a. Perlakuan 0 : Pakan egg custard tanpa penambahan tepung Spirulina.

b. Perlakuan 1 : Pakan egg custard dengan penambahan tepung Spirulina 0,57\%.

c. Perlakuan 2 : Pakan egg custard dengan penambahan tepung Spirulina 1,14\%.

d. Perlakuan 3 : Pakan egg custard dengan penambahan tepung Spirulina 1,72\%

Bahan yang digunakan dalam pembuatan egg custard dapat dilihat pada Tabel 1.

Tabel 1. Bahan yang Digunakan dalam Pembuatan Pakan Egg Custard.

\begin{tabular}{lcccc}
\hline Nama Bahan & $\begin{array}{c}\text { P0 } \\
(\mathbf{g r})\end{array}$ & $\begin{array}{c}\text { P1 } \\
(\mathbf{g r})\end{array}$ & $\begin{array}{c}\text { P2 } \\
(\mathbf{g r})\end{array}$ & $\begin{array}{c}\text { P3 } \\
(\mathbf{g r})\end{array}$ \\
\cline { 2 - 5 } Tepung & 125 & 125 & 125 & 125 \\
$\begin{array}{l}\text { Terigu } \\
\text { Tepung Kanji }\end{array}$ & 10 & 10 & 10 & 10 \\
$\begin{array}{l}\text { Udang Kering } \\
\text { Cumi-cumi }\end{array}$ & 50 & 50 & 50 & 50 \\
$\begin{array}{l}\text { Segar } \\
\text { Ragi Roti }\end{array}$ & 50 & 50 & 50 & 50 \\
$\begin{array}{l}\text { Minyak Ikan } \\
\text { Telur Ayam }\end{array}$ & 5 & 5 & 5 & 5 \\
$\begin{array}{l}\text { Spirulina } \\
\text { kering }\end{array}$ & 0 & 5 & 5 & 5 \\
\hline $\begin{array}{l}\text { Persentase } \\
\text { penambahan }\end{array}$ & $0 \%$ & $0,57 \%$ & $1,15 \%$ & $1,72 \%$ \\
\hline
\end{tabular}


Langkah - langkah dalam pembuatan pakan egg custard sebagai berikut : Siapkan blender untuk mencampurkan bahan baku pakan buatan. Bersihkan bahan kasar yaitu Cumi-cumi dan Udang Kering lalu masukkan kedalam blender, dan masukkan telur. Blender Cumicumi dan Udang Kering sampai halus, lalu masukkan air dan di ikuti bahan halus yaitu tepung terigu, tepung kanji, ragi roti, minyak dan di belender \pm 5 menit (sampai merata), bila telah diblender merata barulah masukkan tepung spirulina dan blender lagi. Setelah pakan tercampur, masukkan adonan pakan buatan egg custard ke dalam wadah loyang. Lalu kukus adonan menggunakan kompor gas selama \pm 20 menit. Kemudian dinginkan. Setelah dingin barulah pakan egg custard di simpan di freezer.

Parameter yang diamati meliputi kelangsungan hidup, perkembangan serta kualitas air.

\section{Kelangsungan Hidup (SR)}

Kelangsungan hidup dinyatakan sebagai persentase jumlah ikan yang hidup dibagi dengan jumlah ikan yang ditebar selama jangka waktu pemeliharaan (Effendie, 1979) yang dinyatakan dengan rumus :

$$
\mathrm{SR}=\frac{\mathrm{Nt}}{\mathrm{No}} \times 100 \%
$$

Keterangan :

$\mathrm{SR}=$ Kelangsungan hidup (\%)

$\mathrm{Nt}=$ Jumlah larva yang hidup akhir (ekor)

No = Jumlah larva yang hidup awal (ekor)

\section{Perkembangan}

Menurut Syafei (2006), larva Udang Galah mengalami 11 tahap perkembangan tubuh yang dimulai setelah menetas sampai dengan pasca larva. Perkembangan larva diamati dengan menghitung Larva Stage Index (LSI) (Hadie dan Supriatna, 1988), dan melihat fase larva menggunakan buku SEAFDEC (2011). Pengamatan dilakukan dengan cara menghitung larva yang memiliki stadium yang sama. Pengamatan stadium larva menggunakan mikroskop pembesar 100 kali. Pengamatan LSI dilakukan setiap 7 hari sekali dimulai larva berumur 7 hari sampai hari ke 28. Rumus untuk menghitung laju perkembangan larva menurut Hadie dan Supriatna (1988), adalah :

$$
\text { Laju Perkembangan Larva }=\mathbf{L S I}_{\mathbf{t}}-\mathbf{L S I}_{\mathbf{a}}
$$

Keterangan :

$\mathrm{LSI}_{\mathrm{t}}=$ Larva stage index hari ke-t

$\mathrm{LSI}_{\mathrm{a}}=$ Larva stage index hari ke-0

Adapun rumusan untuk menghitung LSI menurut Hadie dan Supriatna (1988), adalah :

$$
\mathbf{L S I}=\frac{(n 1 \cdot a)+(n 2 \cdot b)+(n 3 \cdot c)+\ldots-(n t \cdot t)}{\mathrm{N}}
$$

Keterangan:

$$
\begin{array}{ll}
\mathrm{a}, \mathrm{b}, \text { dan } \mathrm{c} & =\text { Stadium larva } \\
\mathrm{n} 1, \mathrm{n} 2 \text { dan } \mathrm{n} 3 & = \\
& \text { Jumlah larva yang dilihat } \\
& \text { pada stadium yang sama } \\
\mathrm{N} & \text { Jumlah total larva }
\end{array}
$$

\section{Parameter Kualitas Air}

Parameter kualitas air yang diamati adalah suhu, $\mathrm{pH}$, oksigen terlarut (DO) dan salinitas. Data yang diperoleh selanjutnya dianalisa secara statistika dengan ragam (ANOVA) dengan sidik ragam pada taraf 5\% (Hanafiah, 2005).

\section{HASIL DAN PEMBAHASAN}

\section{Kelangsungan Hidup}

Hasil pengamatan tingkat kelangsungan hidup larva Udang Galah rata-rata pada akhir penelitian setiap perlakuan dapat dilihat pada Gambar 1

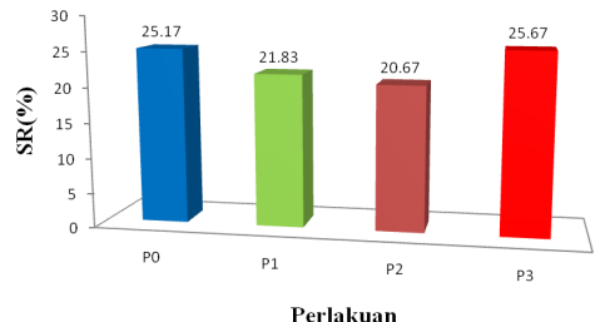

Gambar 1. Kelangsungan Hidup Larva Udang Galah

Hasil ansira terhadap tingkat kelangsungan hidup larva Udang Galah dapat dilihat pada Tabel 2.

Tabel 2. Ansira Tingkat Kelangsungan Hidup Larva Udang Galah

\begin{tabular}{lcccccc}
\hline \multicolumn{1}{c}{ SK } & DB & JK & KT & Fhitung & \multicolumn{2}{c}{ Ftabel } \\
\cline { 5 - 7 } & & & & & $\mathbf{5 \%}$ & $\mathbf{1 \%}$ \\
\hline Perlakuan & 3 & 54,500 & 18,167 & $1,824^{\text {ns }}$ & 4,07 & 7,59 \\
Galat & 8 & 79,667 & 9,958 & & & \\
Total & $\mathbf{1 1}$ & $\mathbf{1 3 4 , 1 6 7}$ & & & & \\
\hline
\end{tabular}

Keterangan : Berpengaruh tidak nyata ${ }^{\text {ns }}$

$\mathrm{KK}=13,52435$

Hasil analisa sidik ragam penambahan tepung spirulina pada pakan buatan larva udang galah menunjukkan hasil berpengaruh tidak nyata dimana $F_{\text {hitung }} 1,824$ lebih kecil dari $F_{\text {tabel }}$
4,07 pada taraf $5 \%$, dengan nilai Koefisien Keragaman (KK) 13,52435. Hal ini di duga penambahan tepung Spirulina menunjukkan 
bahwa tidak mempengaruhi tingkat kelangsungan hidup larva Udang Galah.

Hasil pengamatan tingkat kelangsungan hidup larva Udang Galah pada masing - masing perlakuan setiap sampling dapat di lihat pada Gambar 2.

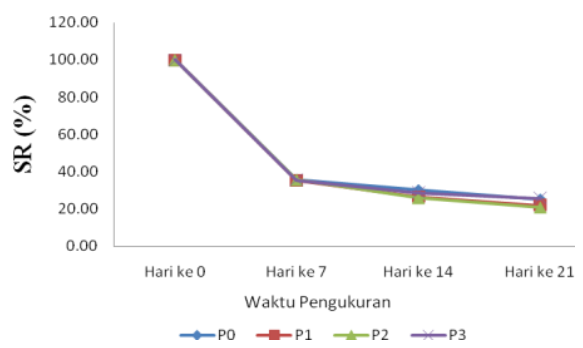

Gambar 2. Tingkat Kelangsungan Hidup per Sampling

Gambar 2 diatas menunjukkan bahwa kematian larva Udang Galah tertinggi terjadi pada awal pemeliharaan. Salah satu faktor yang dapat menyebabkan rendahnya tingkat kelangsungan hidup udang galah yaitu faktor lingkungan. Hal ini dikarenakan pada awal penelitian pengukuran kualitas air untuk kadar amonia sangat tinggi yaitu sebesar $1,40 \mathrm{mg} / \mathrm{l}$. Kisaran optimal amonia Udang Galah sebesar < 0,3 mg/l (New, 2002). Persentase amonia bebas meningkat dengan meningkatnya nilai $\mathrm{pH}$ dan suhu perairan, apabila konsentrasi tinggi dapat mempengaruhi kehidupan Udang (Boyd,1990). Amonia akan berbahaya bagi organisme yang dipelihara karena bersifat racun. Dampak yang ditimbulkan dengan tingginya konsentrasi amonia di air mengakibatkan kondisi kualitas air yang menurun sehingga nafsu makan ikan berkurang dan pakan yang mengendap didasar media pemeliharaan menjadi racun bagi kehidupan Udang Galah. Semakin tinggi kepadatan ikan, maka feses dan urin yang dikeluarkan akan semakin banyak (Irianti, dkk, 2016).

Sisa pakan yang terdapat di dasar wadah merupakan komponen yang dapat memicu peningkatan amonia (Boyd, 1990). Untuk mencegah tingginya amonia karena sisa pakan Tabel 4. Ansira Perkembangan LSI Larva Udang Galah

\begin{tabular}{lcccccc} 
& SK & DB & JK & KT & $\mathbf{F}_{\text {hitung }}$ & \multicolumn{2}{c}{$\mathbf{F}_{\text {tabel }}$} \\
\cline { 5 - 7 } & & & & & $\mathbf{5 \%}$ & $\mathbf{1 \%}$ \\
\hline Perlakuan & 3 & 0,030 & 0,010 & $1,116^{\text {ns }}$ & 4,07 & 7,59 \\
Galat & 8 & 0,072 & 0,009 & & & \\
\hline Total & $\mathbf{1 1}$ & $\mathbf{0 , 1 0 2}$ & & & & \\
\hline
\end{tabular}

Keterangan : ns = berpengaruh tidak nyata

$\mathrm{KK}=1,3700$

Hasil analisa sidik ragam penambahan tepung Spirulina pada pakan buatan terhadap perkembangan larva Udang Galah menunjukkan hasil berpengaruh tidak nyata dimana $F_{\text {hitung }}$ didasar perairan yang tidak dimakan oleh larva Udang Galah, bisa ditambahkan dengan pemberian probitoik untuk larva Udang Galah. Penambahan bakteri probiotik ke dalam wadah pemeliharaan Udang dapat berfungsi sebagai komplemen sumber pakan dan dapat menekan perkembangan populasi bakteri patogen (Verschuere et al, 2000 dalam Suwoyo dan Mangampa, 2010).

Selain itu juga wadah penelitian larva Udang Galah kecil sehingga ruang gerak larva Udang Galah tidak luas dan mengakibatkan kanibalisme pada larva Udang Galah pada saat moulting. Saat moulting tubuh larva Udang Galah menjadi lunak, karena wadah penelitian yang di pakai kecil dan tidak ada pelindung sehingga larva sangat mudah di serang oleh larva lainnya. Kelangsungan hidup Udang Galah dipengaruhi oleh kebiasaan dari udang galah itu sendiri. Kanibalisme merupakan salah satu sifat hewan crustacea yang terjadi jika Udang mengalami stres, serta kepadatan dalam suatu wadah budidaya maupun kegagalan pada saat ganti kulit (Irianti, dkk, 2016). Sifat kanibal pada Udang Galah dapat diminimalisir dengan memberikan tempat berlindung untuk Udang yang sedang moulting.

\section{Perkembangan LSI (Larva Stage Indeks)}

Data hasil penelitian terhadap perkembangan mutlak LSI (Larva Stage Index) larva Udang Galah (Macrobrachium rosebergii de Man) pada setiap perlakuan dapat dilihat pada Tabel 3.

Tabel 3. Perkembangan Mutlak LSI Larva Udang Galah.

\begin{tabular}{|c|c|c|c|c|c|}
\hline \multirow[t]{2}{*}{ Perlakuan } & \multicolumn{3}{|c|}{ Ulangan } & \multirow[t]{2}{*}{ Jml } & \multirow[t]{2}{*}{ Rerata } \\
\hline & 1 & 2 & 3 & & \\
\hline P0 & 7,03 & 6,90 & 6,94 & 20,87 & 6,96 \\
\hline $\mathrm{P} 1$ & 7,06 & 6,89 & 6,79 & 20,74 & 6,91 \\
\hline $\mathrm{P} 2$ & 6,77 & 6,93 & 6,86 & 20,56 & 6,85 \\
\hline P3 & 7,06 & 6,90 & 7,00 & 20,96 & 6,99 \\
\hline \multicolumn{4}{|c|}{ Jumlah } & 83,13 & 6,93 \\
\hline
\end{tabular}

Hasil ansira perkembangan LSI larva Udang Galah selama penelitian dapat dilihat pada Tabel 4.
1,116 lebih kecil dari $\mathrm{F}_{\text {tabel }}$ 4,07 pada taraf 5\%, dengan nilai Koefisien Keragaman (KK) 1,37008 . Hasil pengamatan perkembangan larva 
Udang Galah pada masing - masing perlakuan setiap sampling dapat di lihat pada Gambar 3.

\section{PERKEMBANGAN}

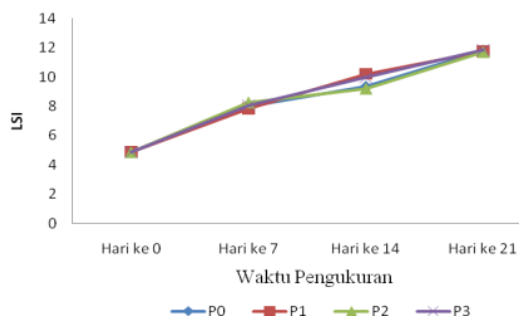

Gambar 3. Perkembangan Larva Udang Galah.

Berdasarkan Gambar 3 dapat dilihat bahwa seluruh perlakuan pada P0 hingga P3 menunjukkan adanya laju perkembangan stadia, tetapi perkembangannya tidak jauh berbeda. Larva Udang Galah mengalami 11 fase perubahan stadia. Antara fase satu dan fase lainnya dapat dibedakan berdasarkan bentuk morfologinya.. Hal tersebut menunjukkan bahwa penambahan tepung spirulina pada pakan buatan terhadap perkembangan larva Udang Galah tidak mempengaruhi perkembangannya. Diduga penyebab tidak adanya perbedaan yang nyata pada perkembangan larva Udang Galah adalah kandungan nutrisi pada pakan masing-masing perlakuan tidak jauh berbeda. Hal ini sesuai dengan penelitian Rosid (2017), dimana penambahan tepung spirulina pada pakan tidak mempengaruhi pertumbuhan ikan. Menurut Sudradjat, dkk., (2003), Faktor yang menyebabkan tidak adanya perbedaan yang nyata pada laju pertumbuhan Udang Galah adalah kandungan nutrisi pada pakan itu sendiri tidak jauh berbeda.

\section{Kualitas Air}

Data parameter kualitas air yang diamati pada penelitian Penambahan tepung Spirulina pada pakan terhadap tingkat kelangsungan hidup dan perkembanangan larva Udang Galah meliputi Suhu, Salinitas, pH, DO dan Amoniak. Hasil pengamatan kualitas air selama penelitian disajikan pada Tabel 5

Tabel 5. Parameter Kualitas Air

\begin{tabular}{lccc}
\hline Parameter & Awal & Akhir & $\begin{array}{c}\text { Kisaran } \\
\text { Optimal }\end{array}$ \\
\hline Suhu $\left({ }^{\circ} \mathrm{C}\right)$ & 28 & 30 & $28-30$ \\
pH & 7,12 & 8,35 & $7-8,5$ \\
DO $(\mathrm{mg} / \mathrm{l})$ & 5,1 & 5,8 & Minimal 3 \\
Salinitas $(\mathrm{ppt})$ & 14 & 15 & $10-15$ \\
Amonia $(\mathrm{mg} / \mathrm{l})$ & 1,17 & 1,40 & 0,03 \\
\hline
\end{tabular}

Kualitas air dalam budidaya Udang Galah memegang peranan yang sangat penting. Kualitas air dapat didefinisikan sebagai kesesuaian air bagi kelangsungan dan pertumbuhan Udang Galah, yang umumnya ditentukan oleh beberapa parameter kualitas air (Mahasri dkk., 2009). Lingkungan perairan yang digunakan untuk pemeliharaan Udang Galah harus memenuhi parameter fisik, kimia, dan biologi. Selain itu, lokasi pemeliharaan hendaknya jauh dari kegiatan lain yang menggunakan atau menghasilkan pestisida, logam berat, dan bahan lain yang dapat menimbulkan kematian Udang. Secara umum parameter kualitas air yang perlu berupa: derajat keasaman (pH), Dissolved Oxygen (DO) atau oksigen terlarut, suhu, salinitas dan ammonia (New, 2002).

\section{a. Suhu}

Berdasarkan hasil pengukuran selama penelitian 21 hari, yaitu suhu terendah $28^{\circ} \mathrm{C}$ dan tertinggi $30{ }^{\circ} \mathrm{C}$. Berdasarkan SNI (2015), kisaran suhu pada larva Udang Galah berkisar 28-30 ${ }^{\circ} \mathrm{C}$, dengan demikian kisaran suhu air selama penelitian masih dalam kondisi layak untuk pertumbuhan larva Udang Galah. Hal ini sependapat dengan Tidwell et al., (2002) dalam Tantri (2014) yang memberikan batasan nilai toleransi udang galah terhadap suhu pada kisaran $25{ }^{\circ} \mathrm{C}$ sampai $32{ }^{\circ} \mathrm{C}$. Kondisi perairan dengan suhu dibawah $25{ }^{\circ} \mathrm{C}$ menyebabkan proses kematangan seksual udang galah terganggu, sehingga menyebabkan sebagian energi yang seharusnya digunakan untuk pertumbuhan dialihkan untuk proses kematangan seksual. Udang Galah masih dapat hidup dalam waktu singkat pada suhu $19{ }^{\circ} \mathrm{C}$ atau diatas $34{ }^{\circ} \mathrm{C}$, sedangkan pada suhu $13{ }^{\circ} \mathrm{C}$ dapat menyebabkan kematian pada Udang (Tidwell et al., 2002 dalam Tantri, 2014).

\section{b. $\mathbf{p H}$}

Berdasarkan hasil pengukuran selama penelitian, $\mathrm{pH}$ berkisar antara 7,12 - 8,15. Berdasarkan SNI (2015), kisaran $\mathrm{pH}$ pada larva udang galah sebesar $7-8,5$, dengan demikian kisaran $\mathrm{pH}$ air selama penelitian masih dalam kondisi layak untuk pertumbuhan larva Udang Galah. Hal ini sesuai dengan pendapat D’Abramo et al., (2006) dalam Tantri (2014), yang menyatakan nilai pH optimal dalam pemeliharaan udang galah berkisar antara 7 8 ,5. Pada lingkungan perairan dengan $\mathrm{pH}$ kurang dari 6,5 atau lebih dari 9,5 udang galah dewasa masih dapat hidup dengan pertumbuhan yang sangat lambat, namun $\mathrm{pH}$ lebih dari 9 dapat menyebakan kematian pada juvenile Udang Galah.

\section{c. DO}

Hasil pengukuran Dissolved Oxygen (DO) selama penelitian berkisar antara 5,1 5,8 . Kondisi oksigen terlarut ini masih layak 
untuk pertumbuhan dan kelangsungan hidup larva Udang Galah. Sesuai dengan SNI (2015), kisaran minimal untuk larva Udang Galah sebesar $3 \mathrm{mg} / \mathrm{l}$. Menurut D'Abramo et al., (2006) dalam Tantri (2014), menyatakan bahwa kandungan oksigen terlarut sebesar $3 \mathrm{mg} / \mathrm{l}$ atau lebih dalam perairan sudah mendukung kehidupan Udang Galah secara normal. Kandungan oksigen terlarut didalam air dibutuhkan untuk respirasi Udang Galah tidak boleh kurang dari $5 \mathrm{mg} / \mathrm{l}$ karena dapat mencegah timbulnya stres pada Udang (D’Abramo et al., 2009 dalam Tantri 2014).

\section{d. Salinitas}

Hasil pengukuran Salinitas selama penelitian berkisar 13-15 ppt. Kondisi ini masih layak untuk perkembangan larva Udang Galah, sesuai dengan SNI (2015), berkisar antara 10-15 ppt. Udang Galah membutuhkan lingkungan perairan tawar dan perairan payau. Pada fase juvenile hingga Udang Galah dewasa membutuhkan perairan tawar, sedangkan fase larva hingga postlarva membutuhkan perairan payau (Pusat Penyuluhan Kelautan dan Perikanan, 2011). Larva dapat hidup pada perairan payau dengan salinitas 9 - 19 ppt. Postlarva dapat hidup pada range salinitas yang besar, sedangkan pertumbuhan postlarva yang optimal membutuhkan lingkungan perairan tawar (D’Abramo dan Brunson, 1996 dalam Tantri, 2014).

\section{e. Amonia}

Hasil pengukuran amonia pada awal penelitian sebesar $1,17 \mathrm{mg} / \mathrm{l}$. Kondisi ini sangat berpengaruh pada tingkat kelangsungan hidup dimana menurut New M.B (2002) kandungan amonia yang optimal bagi budidaya Udang adalah $<0,3 \mathrm{mg} / \mathrm{l}$. Dalam budidaya sisa pakan dalam bentuk feses atau yang tidak termakan berperan besar dalam penurunan kualitas air, ditandai dengan kandungan amonia yang tinggi. Secara ideal konsentrasi ammonia yang terkandung dalam air tidak boleh lebih dari 1 $\mathrm{mg} / \mathrm{l}$. Kadar ammonia yang terlalu tinggi dapat menghambat pertumbuhan dan dalam jangka panjang dapat menyebabkan kematian (Tidwell et al., 2002 dalam Tantri 2014).

\section{KESIMPULAN DAN SARAN}

\section{Kesimpulan}

Berdasarkan hasil penelitian yang telah dilakukan, dapat disimpulkan bahwa :

a. Dosis terbaik pada penelitian ini dalam penambahan tepung spirulina pada pakan terhadap tingkat kelangsungan hidup dan perkembangan larva udang galah masih belum didapatkan di duga karena dosis yang di gunakan masih kurang efektif.

b. Tingkat Kelangsungan hidup larva udang galah pada akhir penelitian setiap perlakuan yaitu P3 25,67\%, P0 25,17\%, P1 21,83\% dan P2 20,67\%.

c. Perkembangan larva udang galah dari awal penelitian sampai selesai penelitian mulai dari stadia 4,86 sampai stadia 11,85 hal ini menunjukkan bahwa adanya perkembangan pada larva udang galah.

\section{Saran}

Berdasarkan hasil penelitian yang dilakukan, penulis menyarankan dilakukan penelitian lanjutan dengan penambahan dosis tepung spirulina untuk mendapatkan pengaruh tingkat kelangsungan hidup dan perkembangan larva Udang Galah.

\section{DAFTAR PUSTAKA}

Effendie, M. I. 1979. Biologi Perikanan. Dewi Sri. Bogor.

Boyd, C.E., 1990. Water Quality in Ponds for Aquaculture. Auburn University. Alabama.

Firdiyani, F., Agustini, T.W. dan Ma'ruf, W.F. 2015. Ekstraksi Senyawa Bioaktif sebagai Antioksidan Alami Spirulina platensis Segar dengan Pelarut yang Berbeda. Journal IPB 18(1):28-37.

Hadie, L.E dan Supriatna. 1988. Pengembangan Udang Galah dalam Hatchery dan Budidaya. Kanasius. Yogyakarta. Hal 99.

Hanafiah, K.A. 2005. Teori dan Aflikasi Rancangan Percobaan. Raja Grafindo Persada. Jakarta.

Irianti, D. S. A, Yustiati, A dan Hamdani, H. 2016. Kelangsungan Hidup Dan Pertumbuhan Udang Galah (Macrobrachium rosenbergii) Yang Diberi Kentang Pada Media Pemeliharaan. Jurnal Perikanan Kelautan 7(1) : Hal 23-29

Mahasri, G., A. S. Mubarak dan M. A. Alamsjah. 2009. Bahan Ajar: Manajemen Kualitas Air. Fakultas Perikanan dan Kelautan. Universitas Airlangga. hal. 7.

New, M. B. 2002. Farming freshwater prawns: A Manual for the Culture of the Giant River Prawn (Macrobrachium rosenbergii). Food and Agriculture Organization (FAO). The United Nations. Rome. pp. 3, 12, 13.

Priyono, S.B., Sukardi. dan Harianja, B.S.M. 2011. Pengaruh Shelter Terhadap 
Perilaku dan Pertumbuhan Udang Galah. Jurnal Perikanan (Journal of Fisheries Sciences) 13( 2):78-85.

Pusat Penyuluh Kelautan dan Perikanan. 2011. Kementerian Kelautan dan Perikanan. Jakarta. Hal 3

Rohmana, D. 2017. Inovasi Produksi Udang Galah. Departemen Kelautan dan Perikanan. Direktorat Jenderal Perikanan Budidaya. Balai Besar Perikanan Budidaya Air Tawar Sukabumi. Instalasi Pembenihan Udang Galah.

Rosid, M.M. 2017. Tingkat Pertumbuhan dan Kecerahan Warna Ikan Komet dengan Penambahan Konsentrasi Tepung Spirulina sp pada Pakan. Skripsi, Fakultas Perikanan Universitas PGRI Palembang (tidak dipublikasikan).

Satria. dan Novrizah, R. 2013. Pakan Melayang (Bouyancy Feed) Pengganti Egg Custard untuk Meningkatkan Keseragaman Ukuran dan Survival Rate Larva Udang Galah. Jurnal Biotik 1(1):1-66.

SEAFDEC. 2011. Training Manualon Freshwater parwn (Macrobrachium rosenbergii) Hatchery and Grow-out Operations. SEAFDEC Aquaculture Departmen Binangon Freshwater Station. Binangon, 1940 Rizal. Philippines.

Setyawan, P.E. dan Satria, Y. 2013. Optimalisasi Ekstrak dan uji Stabilitas Phycocyanin dari Mikroalga Spirulina platensis. Jurnal Teknologi Kimia dan Industri 2(2):61-67.

Standar Nasional Indonesia (SNI). 2015. Udang Galah (Macrobrachium rosenbergii, de
Man) Bagian 4: Produksi Benih. Badan Standarisasi Nasional. Jakarta. 6486.4:2015 11 hal.

Sudradjat, A., Azwar, Z.I., Suhenda, N., Djajasewaka, H., dan Hadie, L.S. 2003. Aplikasi Teknologi Pakan dan Peranannya Bagi Perkembangan Usaha Perikanan Budi Daya. Dalam Kusrini, E., Amin, H.M., Suprapti, dan Hidayat, A (Editor). Prosiding Semi - Loka Tahun 2003. Pusat Riset Perikanan Budidaya, Bogor, 9 September 2003.

Suwoyo, H.S., dan Mangampa, M. 2010. Aplikasi Probiotik dengan Konsentrasi Berbeda pada Pemeliharaan Udang Vaname (Litopenaeus vannamei). Prosiding Farum Inovasi Teknologi Akuakultur. Hal 239-247.

Syafei, L.S. 2006. Pengaruh Beban Kerja Osmotik Terhadap Kelangsungan Hidup, Lama Waktu Perkembangan Larva dan Potensi Tumbuh Pascalarva Udang Galah. Disertasi S3. Institut Pertanian Bogor. Bogor. Hal 51-58.

Tantri, A.F. 2014. Penambahan Lisin pada Pakan Komersial terhadap Retensi Protein dan Retensi Energi Udang Galah. Skripsi, Fakultas Perikanan dan Kelautan Universitas Airlangga Surabaya (tidak dipublikasikan).

Utomo, M.T.S. dan Prabakusuma, A. 2009. Formulasi Pembuatab Tablet Hisap Berbahan Dasar Mikroalga Spirulina plantesis sebagai Sumber Antioksidan Alami. Jurnal Sains MIPA 15(3):167176. 